УДК 658.8:005.523

DOI: https://doi.org/10.37320/2415-3583/13.9

Нагорний С.I.

кандидат економічних наук, провідний науковий співробітник науково-дослідного сектору, Сумський державний педагогічний університет імені А.С. Макаренка ORCID: https://orcid.org/0000-0003-0756-8398

Березова С.M.

молодший науковий співробітник науково-дослідного сектору, Сумський державний педагогічний університет імені А.С. Макаренка

\title{
МЕТОДИЧНІ ЗАСАДИ ОЦІНКИ РИНКОВОЇ АДЕКВАТНОСТІ ІДЕЙ ТОВАРНИХ ІННОВАЦІЙ
}

У статті наведено інструментальне наповнення процедури маркетингового тестування для оцінки ринкової адекватності ідей товарних інновацій з метою відбору найперспективніших із них. У наукових праиях широко представлені різні інструменти маркетингового тестування, більшість із яких застосовують формалізовані методи аналізу, але не завжди дають адекватну оиінку рівня перспективності. Тому бажаними є інструменти, щุо характеризуються більи точними результатами такої оцінки. Серед таких інструментів варто відзначити такі методи: контрольних питань, критеріїв фільтрації, оцінної шкали, розрахунку умовного показника якості ідеї, розрахунку рейтингу ідеї, оцінки імовірності ринкового успіху ідеї товару, доданої иінності, управління портфелем проектів тощьо. Вибір конкретного методу є індивідуальним.

Ключові слова: ідея, товарна інновачія, маркетингове тестування, ринкові перспективи, інструментальне забезпечення, відбір, оцінка.

Постановка проблеми. Передумовою створення ринково успішної товарної інновації є довготривалий, кропіткий процес, що передбачає проведення цілого комплексу робіт на кожному етапі інноваційного циклу. Особливо багато таких робіт виконується на початкових його етапах, коли маємо справу з перевіркою ринкової адекватності ідей товарних інновацій. Відомо, що не кожна ідея, яка пройде через всі етапи інноваційного циклу, виявиться успішною. Так, на початку 80-х років на створення однієї успішної ідеї потрібно було розглянути 7 ідей, на початку $90-х$ років - 11 ідей, на початку 00-х років - 58 ідей, сьогодні - 100, а іноді і 200 провальних ідей $[1 ; 2]$. Як бачимо, відбувається стабільне зростання кількості відфільтрованих, без- 
перспективних ідей, а відповідно зростає й обсяг виконуваних робіт на етапі відбору ідей. На цьому етапі ключову роль відіграють інструменти маркетингового тестування, за допомогою яких виконуються процедури оцінки і відбору не просто найкращих інноваційних ідей, а тих, які мають високі ринкові перспективи. А тому неабиякий інтерес становить інструментальне наповнення процедури маркетингового тестування для відбору найперспективніших ідей товарних інновацій.

Аналіз останніх досліджень і публікацій. Серед авторів, у наукових працях яких представлені інструменти маркетингового тестування для оцінки ринкової адекватності ідей товарних інновацій, можна відзначити: А. Длігача, А. Гріффіна, В. Кардаша, Т. Кашицину, Ф. Котлера, Ж. Ламбена, П. Перерву, Н. Чухрай. Більшість із них застосовують формалізовані методи аналізу, але вони не завжди дають адекватної оцінки.

Формулювання цілей статті. Метою дослідження $\epsilon$ аналіз наявного методичного інструментарію до оцінювання ринкових перспектив ідей товарних інновацій із майбутнім заділом на розроблення авторського інструментарію до проведення цієї оцінки.

Виклад основного матеріалу дослідження. 3ростання показника смертності ідей (кількості невдалих ідей на створення однієї успішної) вимагає генерації великої кількості ідей на відповідному етапі інноваційного циклу. Це призводить до зростання обсягу робіт на обробку та оцінку ідей з метою відбору найбільш перспективної. Значні трудовитрати вимагають здійснювати процедуру відбору ідей за два етапи. На першому етапі всі згенеровані ідеї проходять поверхневу внутрішню оцінку. Поверхневий відбір передбачає відсів безперспективних ідей, які несумісні 3 наявним ресурсним забезпеченням підприємства, його ринковими можливостями та/або цілями розвитку або просто $є$ непривабливими для керівництва. На цьому етапі поглиблений аналіз ідей не проводиться через їх величезну кількість, оскільки потрібно дуже швидко та 3 мінімальними витратами виділити перспективні ідеї і відкинути ті, що є безперспективними або непридатними для підприємства. На другому етапі всі відібрані перспективні ідеї детально розглядаються експертами та проходять повномасштабну поглиблену перевірку та оцінку, в тому числі і з участю споживачів.

Через те, що на ранніх етапах інноваційного циклу відсутні надійні і конкретні дані про ємкість майбутнього ринку, величину споживчого попиту, а фінансовий аналіз, напевно, дасть ненадійні результати, як інструменти оцінки і відбору ідей пропонується використовувати методи, що базуються на експертних оцінках. Недоліком цих методів $є$ те, що за такої оцінки можна помилково відсіяти перспективну ідею або, навпаки, прийняти рішення про комерційне виробництво безперспективної ідеї.

Проаналізуємо найбільш корисні методи й інструменти маркетингового тестування для відбору та оцінки ідей.

Метод контрольних питань (або перелік запитанькритеріїв) [3] - дає змогу за допомогою запитаньвимог, визначених експертами, оцінити всі згенеровані ідеї за критерієм їхньої комерційної привабливості. До ідеї нового продукту може бути висунуто не менше 10 запитань-вимог. Кожна з висунених ідей проходить експертну оцінку за визначеними вимогами з подальшим поділом на перспективні та безперспективні ідеї. Наприклад, це можуть бути такі запитання: чи відповідає ідея цілям розвитку підприємства? Чи відповідає ідея потребам і запитам споживачів? Чи існують близькі товари-аналоги на ринку? Відповіді на такі запитання мають бути приведені до такого формату: 1) «Так», «Ні», або «Не визначено»; 2) «Відповідають» чи «Не відповідають». Перспективними будуть ті ідеї, які матимуть найбільшу кількість позитивних відповідей на наведені запитання-вимоги.

Варто зазначити, що метод контрольних запитань проявляє свою ефективність, коли є чіткі відмінності між аналізованими ідеями, і загалом його можна застосовувати як під час поверхневого відбору, так і під час поглибленої перевірки, але вже з більшою кількістю запитань.

Метод критеріїв фільтрації - оцінка і відбір ідей здійснюється експертами за певними критеріями або групами критеріїв фільтрації. Його можна використовувати і на первинному відборі, і під час повномасштабної перевірки ідей. Сьогодні немає єдиної думки про кількість та різновиди критеріїв оцінки та відбору, ïx визначення здійснюється експертами відповідно до товарної, ринкової, галузевої специфіки. Це можуть бути такі групи критеріїв оцінки: загальні, маркетингові, виробничі, науково-технічні, ринкові, фінансові, зовнішньоекономічні, юридичні, екологічні тощо. А кожна група у своєму складі містить низку одиничних критеріїв.

Слід відзначити, що питання критеріальної оцінки і відбору ідей підіймали у своїх працях не тільки науковці, а і всесвітньо відомі консалтингові компанії. Так, компанія Nielsen [4] для оцінки ринкових шансів та можливостей нового товару запропонувала ринкові, товарні, збутові та виробничі критерії, а консалтингова група MDA [5] розробила матрицю попередньої оцінки комерційних шансів нового товару, в якій привабливість та конкурентоспроможність товару є головними чинниками його успіху (критеріями фільтрації).

Метод оцінної шкали - оцінка і відбір нових ідей здійснюються експертами за певними групами критеріїв фільтрації з урахуванням їхньої вагомості. Цей метод використовується в такій послідовності: визначення переліку груп критеріїв оцінки та одиничних критеріїв, що наповнюють ці групи; визначення ваги як кожного одиничного критерію, так і кожної групи критеріїв; присвоєння експертами кожній ідеї певного бала за кожним одиничним критерієм; визначення загальної оцінки. Цей метод подібний до методу критеріїв фільтрації, але оцінка ідеї відбувається шляхом зважування іiі основних чинників. Цей метод можна використовувати і для попереднього відбору всіх згенерованих ідей, і для розгорнутої оцінки відібраних перспективних ідей. Розгорнута оцінка повинна мати більшу кількість груп та факторів, ніж попередня.

Як приклад, пропонуємо таку оцінну шкалу перспективності ідеї товарної інновації (табл. 1).

Наведена шкала оцінюється від 0 до 10 балів. Перспективною є ідея, що отримала оцінку від 7,5 до 10,0 балів.

Метод розрахунку умовного показника якості ідеї [5]. Процедура оцінки зводиться до такого: спочатку формується список ключових факторів успіху 
Таблиця 1 - Оцінна шкала перспективності ідеї (фрагмент)

\begin{tabular}{|c|c|c|c|c|c|}
\hline Група критеріїв & $\begin{array}{c}\text { Вага групи } \\
\text { критеріїв }\end{array}$ & Одиничні критерії & Вага критерію & $\begin{array}{l}\text { Бальна оцінка } \\
\text { критерію* }\end{array}$ & $\begin{array}{c}\text { Сумарна оцінка } \\
\text { за критерієм } \\
\text { та групою } \\
\end{array}$ \\
\hline \multirow{4}{*}{$\begin{array}{l}\text { Критерії } \\
\text { стратегічного } \\
\text { управління } \\
\text { підприємства }\end{array}$} & \multirow{4}{*}{$V_{l}$} & Прибутковість & $v_{11}$ & $x_{11}$ & $s_{11}$ \\
\hline & & ... & $\ldots$ & $\ldots$ & $\ldots$ \\
\hline & & Ризик & $v_{l i}$ & $x_{l i}$ & $s_{l i}$ \\
\hline & & Загалом по групі & 1,00 & - & $S_{I}=\sum s_{l i}$ \\
\hline \multirow{4}{*}{ Ринкові критерії } & \multirow{4}{*}{$V_{2}$} & Місткість ринку & $v_{21}$ & $x_{21}$ & $s_{21}$ \\
\hline & & .. & $\ldots$ & $\ldots$ & $\ldots$ \\
\hline & & Рівень конкуренції & $v_{2 i}$ & $x_{2 i}$ & $s_{2 i}$ \\
\hline & & Загалом по групі & 1,00 & - & $S_{2}=\sum s_{2 i}$ \\
\hline \multicolumn{6}{|l|}{$\ldots$} \\
\hline \multirow{4}{*}{$\begin{array}{l}\text { Інтелектуальні та } \\
\text { науково-технічні } \\
\text { критерії }\end{array}$} & \multirow{4}{*}{$V_{j}$} & Освітній рівень персоналу & $v_{i 1}$ & $x_{i 1}$ & $s_{i 1}$ \\
\hline & & $\ldots$ & $\ldots$ & $\ldots$ & $\ldots$ \\
\hline & & Інформаційне оснащення & $v_{i i}$ & $x_{i i}$ & $s_{j i}$ \\
\hline & & Загалом по групі & 1,00 & - & $S_{j}=\sum s_{j i}$ \\
\hline Загальна оцінка & 1,00 & & - & - & $\sum S=\sum V_{j} \cdot S_{j}$ \\
\hline
\end{tabular}

* $i$ - кількість одиничних критеріїв; $j$ - кількість їх груп.

нової ідеї в кожній функціональній сфері (маркетинг, фінанси, виробництво, НДДКР), далі кожному фактору або групі факторів присвоюється вагомість, а потім відбувається оцінка кожної ідеї за всіма факторами успіху й обчислюється умовний показник якості ідеї.

Показник якості доцільно обчислювати не просто як середньозважену оцінку, а за допомогою кон'юнктивного методу. Цей метод дає змогу встановити сумісність чи несумісність ідеї з цілями або ресурсами підприємства. Він вимагає визначення максимального і мінімального рівнів для кожного нового проекту. Відбір проходять тільки ті ідеї, які перевищують всі встановлені порогові рівні.

Цей метод відбору можна застосовувати під час поверхневого відбору для визначення перспективних ідей.

Методика розрахунку рейтингу ідеї нового товару $[6 ; 7 ; 8]$ - передбачає експертну оцінку вимог що висуваються до ідеї (або чинників, які необхідні для успішного запуску ідеї в комерційне виробництво, і ступінь їх присутності в ідеї). Вимоги до ідей мають бути проранжовані за значущістю та оцінені в балах, наприклад, від 0 до 10. За результатами сумарного підрахунку рейтингу ідею, що отримала від 7,5 до 10,0 балів, відносять до перспективної (табл. 2).

Цей метод можна використовувати для попереднього відбору перспективних ідей із загальної кількості всіх згенерованих ідей.

Метод стандартних бланків оцінки [7] (або стандартне оформлення пропозиції [6]). Експертна оцінка і відбір ідей за стандартними бланками (візуально схожі на преамбулу до бізнес-плану), в яких наводяться основні ii характеристики: маркетинговий опис, величина і потенціал ринку, рівень задоволення потреб, реальні і потенційні конкуренти, сума необхідних інвестицій тощо. Експерти здійснюють розгляд та оцінку цих бланків з метою відібрати не просто ідеї, які мають хороші ринкові перспективи, а тільки ті, що відповідають профілю підприємства, узгоджуються 3 його цілями, стратегічними установками і ресурсами. Метод стандартних бланків доцільно використовувати для попереднього відбору перспективних ідей.

Чек-листи - це оціночні бланки для перевірки ідей за різними оціночними переліками. Ці бланки мають зручний для проведення перевірок вигляд (табл. 3). Оціночними переліками можуть бути різні показники, фактори, критерії тощо, що об'єднані в одну комплексну категорію, наприклад потенціал інноваційного розвитку, ринковий потенціал, інноваційний ризик тощо. У [7] такою комплексною категорією є інноваційний ризик, а оціночний перелік складається з переліку всіх можливих ризиків, які можуть мати місце на етапах інноваційного циклу розроблення нового продукту.

За результатами оцінки визначається сума позитивних і негативних відповідей. Чим більшою $є$ кількість позитивних відповідей, тим більший інноваційний ризик і тим менш приваблива ідея. Метод використання чек-листів доцільно використовувати для попереднього відбору перспективних ідей нових продуктів.

Метод оцінки імовірності успіху ідеї нового товару $[6 ; 7]$. Цей метод передбачає розгляд всіх згенерованих

Таблиця 2 - Розрахунок рейтингу ідей нових товарів

\begin{tabular}{|l|c|c|c|}
\hline \multicolumn{1}{|c|}{ Вимоги до ідеї нового товару } & Вагові коефіціснти & $\begin{array}{c}\text { Оцінка } \\
\text { за 10-бальною шкалою }\end{array}$ & Оцінка рейтингу \\
\hline Новизна ідеї & 0,4 & 8,5 & 3,4 \\
\hline Оптимальне співвідношення «ціна/якість» & 0,3 & 6,1 & 1,83 \\
\hline Бюджет маркетингової програми & 0,1 & 3,0 & 0,3 \\
\hline Відсутність конкуренціі & 0,1 & 5,5 & 0,55 \\
\hline Наявність інфраструктури & 0,05 & 6,3 & 0,32 \\
\hline Наявність фінансового забезпечення & 0,05 & 8,2 & 0,41 \\
\hline Разом & 1,0 & - & 6,81 \\
\hline
\end{tabular}


Таблиця 3 - Чек-листи оцінки інноваційних ризиків (фрагмент)

\begin{tabular}{|c|c|c|}
\hline \multicolumn{1}{|c|}{ Оціночні переліки інноваційних ризиків } & \multicolumn{2}{|c|}{ Оцінка } \\
\cline { 2 - 3 } & & Так \\
\hline Ризик порушення термінів розроблення конструкції: & + & \\
\hline - неправильне завантаження групи проектувальників; & + & \\
\hline - низька пропускна спроможність служб з відбору ідей; & & \\
\hline Ризик невідповідності розробленої конструкції ідеї товару: & + & \\
\hline - недостатній досвід і кваліфікація конструкторів; & + & \\
\hline - недостатня інформованість конструкторів про ідею товару; & \\
\hline - неузгодженість у роботі конструкторів з працівниками інших підрозділів; & & \\
\hline Ризик неадекватної оцінки можливостей виробництва і збуту: & + & + \\
\hline - необ'єктивність аналізу; & & \\
\hline - недооцінка чи переоцінка можливостей виробництва; & + & \\
\hline - помилки у формуванні системи розподілу і товароруху; & & \\
\hline - помилки, допущені на попередніх етапах. & & + \\
\hline Разом & 6 & 3 \\
\hline
\end{tabular}

ідей нових продуктів за інтегральним показником імовірності успіху (зважена оцінка ймовірностей технічного завершення створення продукту, запуску його у виробництво, комерційної реалізації). До поглибленого розгляду проходять ідеї 3 найбільшою імовірністю успіху. Цей метод оцінки не визначає, яким чином здійснюється розрахунок складників формули, і в цьому вбачається недолік цього методу.

Метод доданої цінності. Цей метод дає змогу визначити і проаналізувати відносний внесок кожної ідеї в досягнення тактичних та стратегічних цілей розвитку підприємства. Як приклад, наведемо таку ієрархію цілей підприємства (табл. 4) [8].

Загалом друга ідея $є$ кращою, оскільки вносить більше сукупного вкладу в досягнення цілей розвитку підприємства (85 із 100), ніж перша ідея (70 із 100).

Цей метод можна використовувати як для попереднього відбору перспективних ідей із загальної кількості всіх згенерованих ідей, так і для поглибленого аналізу вже відібраних ідей. Проте варто відзначити, що для поглибленого аналізу метод $є$ більш застосовним, оскільки він належить до трудомістких за процедурою проведення.

Відсів ідей за допомогою методу управління портфелем проектів. Суть полягає в тому, аби ставитися до ідеї нового товару як до інвестицій і застосовувати до них концепції управління інвестиційним або фінансовим портфелем. Популярним методом, що дає змогу наочно змалювати портфель ідей нових товарів, $\epsilon$ матриця, яку запропонував Р. Куперт, у якій розміщуються залежно від «успіху технічної чи/або комерційної реалізації» і «цінності (привабливості) проекту для компанії» всі ідеї зі створення нових продуктів: «перлини», «золоті жили», «засоби для існування», «нікчемні речі». Перспективними ідеями $\epsilon$ «перлини» та «золоті жили».

Перевагою портфельних методів $є$ те, що вони розглядають усі ідеї одночасно, а не окремо, і дають змогу наочно побачити всі перспективні ідеї на матриці. Цей метод використовують для поверхневого відбору перспективних ідей. Для поглибленого аналізу цей метод не підходить, оскільки всі перспективні ідеї знаходяться в одному квадранті.

Окрім матриці, Р. Купер пропонує і свою систему діагностики та відбору ідей [5]. Ї̈і суть зводиться до такого. Експерти заповнюють анкету з 30 питанькритеріїв. Кожен критерій оцінюється за 10-бальною шкалою. Крім того, кожен експерт вказує свій ступінь впевненості в оцінці (теж за 10-бальною шкалою). Далі складається профіль проекту, який потім порівнюється 3 профілями сотень інших проектів із банку даних NewProd. Ця імітаційна модель дає змогу оцінити ймовірність успіху нового товару, а також проаналізувати сильні і слабкі місця проекту. Імітаційну модель NewProd доцільно використовувати як для поверхневої оцінки всіх згенерованих ідей, так і для їх поглибленої оцінки.

Також для поглибленої оцінки відібраних перспективних ідей можна використовувати стандартні маркетингові дослідження споживачів. Під час цих досліджень визначають найбільш значущі та привабливі для споживачів ідеї інноваційних товарів. Але слід зазначити, що маркетингові дослідження потрібно виконувати на другому етапі, під час повномасштабної пере-

Таблиця 4 - Ієрархія цілей підприсмства

\begin{tabular}{|l|c|c|c|}
\hline \multirow{2}{*}{ Цілі підприсмства } & \multirow{2}{*}{ Відносна цінність } & \multicolumn{2}{|c|}{ Цінність, яку вносить ідея } \\
\cline { 3 - 4 } & & Ідея 1 & Ідея 2 \\
\hline Тактичні (на 1-2 роки): & 60 & 35 & 30 \\
\hline Забезпечення щорічного прибутку & 35 & 25 & 25 \\
\hline Збереження потоку готівки & 25 & & 25 \\
\hline Стратегічні (5 років): & 40 & 10 & 5 \\
\hline Збільшення частки ринку до, \% & 25 & 0 & 85 \\
\hline Досягнення лідерства з витрат & 15 & 70 & \\
\hline Загальний внесок у додавання цінності & 100 & & \\
\hline
\end{tabular}


вірки всіх відібраних перспективних ідей. Це пов'язано 3 тим, що на першому етапі здійснюється поверхнева оцінка і відбір значної кількості ідей, і участь споживачів на цьому етапі значно уповільнить цей процес та призведе до значного зростання витрат на проведення досліджень, що суперечить основній меті первинного відбору (дуже швидко та 3 мінімальними витратами виділити перспективні ідеї із загальної кількості згенерованих).
Висновки. Розглянуті вище методи оцінки і відбору інноваційних ідей $є$ найбільш застосовуваними, і більшість із них належить до формалізованих, що не завжди дають адекватну оцінку рівня перспективності. А тому на етапі відбору ідей бажаними є інструменти, що характеризуються більш точними результатами маркетингового тестування 3 оцінки ринкових перспектив ідей товарних інновацій, що і становить перспективи подальших досліджень.

\section{Список використаних джерел:}

1. Griffin A. PDMA Research on New Product Development Practices: Updating Trends and Benchmarking Best Practices. Journal of product innovation management. 1997. № 14. P. 429-458. DOI: 10.1016/S0737-6782(97)00061-1

2. Длигач А. Проектное управление в маркетинге. Новый маркетинг. 2009. № 5. С. 41-44.

3. Чухрай Н., Патора Р. Товарна інноваційна політика: управління інноваціями на підприємстві. Київ : КОНДОР, 2006.398 с.

4. Кардаш В.Я., Павленко І.А., Шафалюк О.К. Товарна інноваційна політика. Київ : КНЕУ, 2002. 266 с.

5. Ламбен Жан-Жак. Менеджмент, ориентированный на рынок. Санкт-Петербург : Питер, 2005. 800 с.

6. Маркетинговий менеджмент / Ф. Котлер, К.Л. Келлер, А.Ф. Павленко та ін. Київ : Хімджест, 2008. 720 с.

7. Економіка та організація інноваційної діяльності / за ред. П. Перерви, С. Меховича, М. Погорєлова. Харків : НТУ «ХПІ», 2008. $1080 \mathrm{c}$

8. Кашицына Т.Н. Экспертиза инновационных проектов. Владимир : Изд-во ВлГУ, 2012. 58 с.

\section{References:}

1. Griffin, A. (1997). PDMA Research on New Product Development Practices: Updating Trends and Benchmarking Best Practices. Journal of product innovation management, 14, 429-458. doi: https://doi.org/10.1016/S0737-6782(97)00061-1

2. Dligach, A. (2009). Proektnoe upravlenie v marketing [Project management in marketing]. Novyy marketing [New marketing], № 5, 41-44. (in Russian)

3. Chukhray, N., Patora, R. (2006). Tovarna innovatsiyna politika: upravlinnya innovatsiyami na pidpriemstvi [Commodity Innovation Policy: Innovation Management at the Enterprise]. Kyiv: Kondor. (in Ukrainian)

4. Kardash, V.Ya., Pavlenko, I.A., Shafaliuk, O.K. (2002). Tovarna innovatsiina polityka [Commodity innovation policy]. Kyiv. (in Ukrainian)

5. Lambin, J.-J. (2005). Menedzhment, orientirovannyy na rynok [Market oriented management]. St. Petersburg: Peter. (in Russian)

6. Kotler, F., Keller, K.L., Pavlenko, A.F. (2008). Marketynghovyj menedzhment [Marketing management]. Kyiv: Khimdzhest. (in Ukrainian)

7. Pererva, P., Mekhovych, S., Pohorielov, M. (2008). Ekonomika ta orhanizatsiia innovatsijnoi diial'nosti [Economics and organization of innovation activities]. Kharkiv: NTU «KhPI». (in Ukrainian)

8. Kashitsyna, T.N. (2012). Ekspertiza innovatsionnykh proektov [Expertise of innovative projects]. Vladimir: VlGU. (in Russian)

Nagornyi Yeugene, Berezova Svitlana Sumy State Pedagogical University named after A.S. Makarenko

\section{METHODICAL BASES OF AN ESTIMATION OF MARKET ADEQUACY OF COMMODITY INNOVATIONS IDEAS}

Creating a market-successful product innovation involves a whole range of works at each stage of the innovation cycle. Especially many such works are performed at the stage of selection of ideas for product innovations, when we are dealing with checking their market adequacy. At this stage, a key role is played by marketing testing tools, which are used to evaluate and select not just the best innovative ideas, but those that have high market prospects. Therefore, the instrumental content of the marketing testing procedure for the selection of the most promising ideas of product innovation is of great interest, which is the purpose of this study. The article presents the instrumental content of the marketing testing procedure for assessing the market adequacy of product innovation ideas in order to select the most promising of them. Due to the fact that in the early stages of the innovation cycle there are no reliable and specific data on future market capacity, consumer demand, and financial analysis is likely to give unreliable results, as tools for evaluating and selecting promising ideas, scientists suggest using methods based on expert estimates. The disadvantage of these methods is that the ideas are considered in isolation, and does not take into account the impact of any of them on the overall allocation of resources throughout the portfolio of new product projects. Besides, it is necessary to consider that at similar assessment it is possible to eliminate mistakenly the perspective idea, or on the contrary to make decisions on development and commercial production unpromising idea. Among the alternative methods of evaluation and selection of ideas should be noted: the method of control questions, the method of filtering criteria, the method of evaluation scale, the method of calculating the conditional quality of the idea, the method of calculating the rating of the idea of a new product, method of standard evaluation forms, checklists, method of estimating the probability of success of a new product idea, method of added value, method of project portfolio management. The choice of a particular method is individual, and depends on the specifics of the product, market, industry, management attitude, and so on. The obtained results develop the theory of innovation marketing in terms of assessing the market adequacy of product innovation ideas.

Key words: idea, product innovation, marketing testing, market prospects, tool maintenance, selection, evaluation.

JEL Classification: O31, O33, M20, M31 